\title{
Incentive Plans, Pay-for-non-financial Performance and ESG Criteria: Evidence from the European Banking Sector
}

\author{
Elisabetta D“Apolito ${ }^{1}$, Antonia P. Iannuzzi ${ }^{2}$ \\ ${ }^{1}$ Department of Economics, University of Foggia, Foggia, Italy \\ ${ }^{2}$ Ionian Department of Law, Economics and Environment, University of Bari, Italy \\ Correspondence: Elisabetta D’Apolito, Department of Economics, University of Foggia, Foggia, 71121, Italy.
}

Received: August 5, 2017

doi:10.5539/ibr.v10n10p169
Accepted: August 24, 2017

Online Published: September 25, 2017

URL: https://doi.org/10.5539/ibr.v10n10p169

\begin{abstract}
The new regulations of banking compensation following the sub-prime crisis require that incentive plans must be linked not only to performance parameters, but also to non-financial or qualitative metrics related to social value produced by banks. This paper aims to analyze this issue by developing a qualitative rating (ESG-remuneration performance rating) to be used not only to investigate the spread and the diversification of such qualitative indicators, but also to analyze the best practices by banks. At a methodological level, the content analysis approach is adopted. The sample covers all of the "European globally systemically important institutions" (G-SIIs), while the investigation period regards the three-years 2014-2016. The main results are encouraging as they show a good diffusion of qualitative metrics by bank incentive plans; however, the intensive use, synthesized by the "ESG-remuneration performance rating", is still inadequate. Moreover, the analysis reveal other criticalities linked to the implementation of the balance scorecard and the use of measurement tools in order to quantify the qualitative metrics correctly. (Note 1 ).
\end{abstract}

Keywords: banking compensation, non-financial performance indicators, ESG criteria, content analysis

\section{Introduction}

A particularly important issue of the new legislation on banking compensation following the sub-prime crisis regards the strengthening of the "pay-for-performance principle" (FSB, 2009; CEBS, 2010; EBA, 2015). Through this principle, the Supervisory Authorities aim to fortify the correlation between the incentive pay and the firm's performance so that each manager can really contribute to the bank value creation, especially from a long-term perspective (Banker et al., 2000; Belcredi and Ferrarini, 2013; Flammer et al., 2016). In line with this legislative constraint, another central issue, on which this paper will focus, is the inclusion, among the performance measurement tools, also non-financial or qualitative metrics, that are linked to the "social" performance achieved by a bank. In other words, in addition to the financial results, prior to granting equity incentives, the legislator urges banks to also verify the pursuit of corporate social responsibility goals linked to the value creation in a stakeholder view. As the Supervisory Authorities point out, examples of such "qualitative performance measures" or "ESG criteria" (Nota 2), are referable to customer satisfaction goals, to strategic choices, in compliance with both internal and external rules to the bank, to strengthen the stakeholder engagement level (BCBS, 2011). This legislative innovation appears to be very important as it not only enhances the overall performance risk adjustment process of bank remuneration practices, by introducing "a different lens through which performance is measured" (BCBS, 2011: 18), but also because it could become a brake for the widespread and indiscriminate assignment of incentive pay. Some Supervisors state that any non-ethical behavior of the manager (or not in line with the qualitative performance criteria) might exclude the allocation of bonus/equity incentives even if the economic performance achieved by him was satisfactory (CEBS, 2010; BCBS, 2010).

At the operational level, the adoption of non-financial metrics in corporate pay-packages is certainly more recent (compared to the use of financial indicators, Banker et al., 2000) and can be connected both to the solicitations received by regulators and to the shareholders activism phenomenon which, howe ver, has known a new phase of auge following the sub-prime mortgages crisis (Iannuzzi, 2013). The latest data, indeed, highlight the growing sensitivity of companies and the professional world to this problem (Ittner et al., 1997; New Bridge Street, 2012; KPMG, 2015; Flammer et al., 2016). More and more frequently the success, the reputation and the credibility of 
the CEO is assessed both on the basis of the economic performance achieved by these managers and by examining their non-financial performance (ESG performance). This in order to take account of "many aspects of leadership that go beyond mere market performance" (Harvard Business Review, 2015. 50). At the doctrinal level, however, literature has not as yet gone into enough depth: up till now a few works analyze this particular aspect of the managerial pay and among these no research investigates only the banking sector (Banker et al., 2000; Miles and Miles, 2011; Maas, 2016), probably due to the (on going) poor propensity of the financial firms to use such qualitative criteria (Abdelmotaal and Abdel-Kader, 2016).

Nevertheless, as the latest Financial Stability Board report on the application by the financial institutions of the new rules on pay packages points out, an area characterized by considerable margins of improvements still regards the development of the quantitative and mostly qualitative performance criteria to which variable remunerations must be anchored (FSB, 2015). Therefore, based on this evidence, this paper aims to deepen the issue of "non-financial performance indicators" and achieve the following research objectives:

a) analyze the spread and frequency (of use) of such metrics by major European banks;

b) verify the quantitative diversification of such indicators and any progress made by banks in recent years with regard to their use;

c) to develop a qualitative rating, to be used not only as a diagnostic tool, but also as a "tableau de bord" in order to address the banks towards a more virtuous behavior and in line with more advanced practices in the field of incentive compensation programs.

The sample covers the universe of the "European globally systemically important institutions" (G-SIIs), while the investigation period regards the three-years 2014-2016. At a methodological level, the study is based on the elaboration of a quantitative score (called ESG-remuneration performance rating) designed to detect the best practices by banks regarding the use of non-financial metrics in their remuneration packages. For this purpose, information is obtained using the "content analysis approach" (Abbott and Monsen, 1979) and by consulting the official documents of each bank (Annual reports, Compensation reports, Corporate Go vernance reports, web site). This study is innovative because it contributes to the existing literature in many ways. First of all, it addresses a still unexplored issue in the banking sector. Indeed, based on current knowledge, the issue of the ESG criteria linked to bank incentive plans has not yet been sufficiently investigated in literature. Secondly, the methodological approach adopted in this paper is more sophisticated because it is based on the elaboration of a synthetic indicator (rating or score). On the contrary, other similar studies investigate the adoption of non-financial metrics by verifying only their presence or absence within the incentive plans, that is their use or not-use by enterprises (indeed, dichotomous variables are usually used, see Hong et al., 2015) without investigating its intersive use and/or compliance level with regulatory requirements or best practices.

The remainder of the study is organized as follows. In Section 2 we review the literature on banking compensation and on the use of non-financial metrics. Section 3 focuses on the research method and the sample used for the assignment of the "ESG-remuneration performance rating" to banks; in Section 4 we present the results while in Section 5 we discuss our empirical findings and provide suggestions for further research.

\section{Literature Review}

As part of the extensive literature on executive compensation, most scientific contributions focus on the analysis of incentive pay, that is on the relationships between the amount of variable remuneration and the economic and financial performance of firms. However, recent research has also begun to develop a further profile of analysis aimed at analyzing existing relationships between variable remuneration and some non-financial performance indicators (or non-financial performance indicators) associated with social and ethical value (Nota 3) produced by enterprises (Uni PRI, 2012; Maas, 2016). This second set of research is based on the stakeholder theory in which the conduct of the CEO and all the Top Management and also their remuneration packages must reflect not only the shareholders expectations but also that of all other stakeholders. Among these, must be cited the customers, the employees, the Supervisory Authorities (for which managerial remuneration must meet prudential objectives) therefore, the society as a whole (Berrone and Gomez-Mejia, 2009a). However, the first studies that analyze the inclusion of qualitative (or non-financial) metrics in remuneration packages focus almost exclusively on environmental performance. The main results appear partial. On the one hand, they highlight how environmental performance is a decisive factor in managerial remuneration (Campbell et al., 2007), confirming a positive relationship between the use of environmental standards, as part of Top Management's remuneration, and the firm's environmental performance. On the other hand, however, this connection is verified only for a few category of managers (Russo and Harrison, 2005), or only for some environmental standards (Cordeiro and Sarkis, 2008). 
More recently, the focus moves onto the study of the relationship between the use of non-financial metrics and the overall corporate ethics performance (or CSR - Corporate Social Responsibility). In this regard, Maas (2016), focusing on about 400 companies for the years 2008-2012 (for a total of 1,846 observations), highlights two very interesting aspects. On the one hand, the level of ethical performance, which characterizes an enterprise, does not seem to have a predictive value for the use of non-financial metrics; on the other, the inclusion of such Key Performance Indicators (KPIs), especially if specific quantitative targets are associated with them, represents a concrete way to improve CSR (Nota 4). On the contrary, Hong et al. (2015: 2), while confirming how "executive compensation for CSR leads to more CSR activities" also note that "a better corporate governance predicts a greater likelihood of observing executive compensation contracts with incentives linked to CSR outcomes" (Hong et al., 2015: 5). In other words, the authors argue that the adoption of a better corporate governance system, with less managerial power, can positively influence the adoption of non-financial metrics, qualifying both as a predictor and as a factor determinant of the use of such parameters. Related results also emerge from a recent study conducted by Vigeo, a renowned social and environmental rating agency. In detail, this company finds that integrating ESG (Environmental, Social, Governance) criteria into managers' remuneration practices has a positive and significant impact on the company's ethical rating. This evidence, although it cannot qualify as a direct causal relationship, however "suggests that CSR-linked executive remuneration can be an important signal and tool of a strategic and comprehensive approach to sustainability and integration of CSR drivers" (Vigeo, 2015: 7). Moreover, further research also reveal a direct relationship between the CSR and the non-financial incentives. That is, not only such non-financial incentives would have a positive influence on the corporate social performance, but also the level of CSR that is the adoption of greater social responsibility practices, even under an organizational profile (Nota 5) could be a determining factor in the use of non-financial metrics in remuneration practices (Hong et al., 2015; Abdelmotaal and Abdel-Kader, 2016). This could happen because companies that adopt more CSR practices also have a better sustainability information system, a circumstance that facilitates the use of non-financial metrics in remuneration schemes. Another explanation lies in the possible disciplinary effect of non-financial metrics whose use should therefore urge managers to implement more sustainability practices.

Finally, a third more recent research area includes, in addition to the analysis of corporate social performance, also the economic ones. The main results of this strand of literature are encouraging. Indeed, the use of ESG criteria in remuneration packages would result in both a reduction in short-termism by management and its social and environmental benefits, and an increase in the corporate value measured by Tobin'Q (Flammer et al., 2016), and finally, a better economic performance (Banker et al., 2000). Additionally, the use of CSR in managerial remuneration would also improve corporate governance by encouraging executives to: a) adopt a longer-term investment horizon; b) focus on stakeholders that contribute more to the sustainable value creation in time; c) undertake more complex, but more effective, initiatives in terms of environmental sustainability (Flammer et al., 2016). In short, the literature review suggests that the effectiveness of non-financial metrics in remuneration packages still requires further insight (Maas, 2016). In detail, the main criticisms concern the methodological system that often only marginally addresses this question (Berrone and Gomez-Mejia 2009b; Cordeiro and Sarkis, 2008) or focuses only on environmental performance (Russo and Harrison, 2005; Cordeiro and Sarkis, 2008). Moreover, most doctrinal contributions seem to be concentrated on non-financial firms. Indeed, and on the basis of this knowledge, no study has been carried out only on the banking sector, despite the fact some recent research reveals how the "pay-for non financial performance" approach is slowly spreading also within the financial industry (Morgan Stanley, 2016).

\section{Data and Methodology}

\subsection{The Sample}

The analysis focuses on the major European banking groups that can be traced back to the uni verse of the global systemically important institutions (so-called G-SIIs) as well as resulting in December 2016 (see, www.eba.com). Among the motivations that led to the selection of such banks is, first and foremost, the dimensional aspect. Larger intermediaries, for both systemic and reputable reasons, are certainly the first subjects to comply with the new rules in force, or to implement "a more sophisticated remuneration policies and risk measurement approaches" (EBA, 2015: 39). This aspect, also highlighted by some empirical surveys (Morgan Stanley, 2016), may depend on both the greater disclosure transparency of the larger companies and the increased pressure of institutional investors who, in the context of their active equity policies, tend to privilege larger firms as they are more exposed to the market (Morgan Stanley, 2016). Secondly, we chose to focus attention on the universe of European G-SIIs because the business models adopted by these banks are fairly uniform. If, on the other hand, the analysis was extended to other international banks, including the US, the sample would have been une ven, 
resulting in specialized banks also in investment banking, which are known to be partially different from economic and financial equilibriums and regulations (De Vincentiis, 2014).

Table 1. European Global Systemically Important Institutions (Total Assets in millions of euro, December 2016)

\begin{tabular}{|c|c|c|}
\hline Banks & Total Assets & Countries \\
\hline HSBC & $2,253.08$ & United Kingdom \\
\hline BNP Paribas & $2,076.96$ & France \\
\hline Deutsche Bank & $1,591.55$ & Germany \\
\hline Credit Agricole & $1,524.23$ & France \\
\hline Barclays & $1,423.47$ & United Kingdom \\
\hline Société Générale & $1,382.24$ & France \\
\hline Banco Santander & $1,339.12$ & Spain \\
\hline BPCE & $1,235.24$ & France \\
\hline Lloyds Banking & 959.59 & United Kingdom \\
\hline Royal Bank of Scotland (RBoS) & 937.14 & United Kingdom \\
\hline Unicredit & 859.53 & Italy \\
\hline ING Groep & 845.08 & Belgium \\
\hline Credit Mutuel & 793.52 & France \\
\hline BBVA & 731.85 & Spain \\
\hline Intesa SanPaolo & 725.10 & Italy \\
\hline Rabobank & 662.59 & Belgium \\
\hline Nordea Bank & 615.65 & Sweden \\
\hline Standard Chartered & 615.13 & United Kingdom \\
\hline DZ Bank & 509.44 & Germany \\
\hline Commerzbank & 480.50 & Germany \\
\hline Danske Bank & 469.11 & Denmark \\
\hline ABN Amro & 394.48 & Netherlands \\
\hline Caixabank & 347.92 & Spain \\
\hline DNB & 292.20 & Norway \\
\hline KBC Groep & 275.20 & Belgium \\
\hline Svenska Handelsbanken & 274.42 & Sweden \\
\hline Skandinaviska Enskilda Banken & 273.70 & Sweden \\
\hline Nationwide & 244.04 & United Kingdom \\
\hline LBBW & 243.62 & Germany \\
\hline Swedbank & 224.98 & Sweden \\
\hline Bayern LB & 212.15 & Germany \\
\hline Erste Bank & 208.22 & Austria \\
\hline BFA & 207.70 & Spain \\
\hline Nykredit & 188.39 & Denmark \\
\hline NordLB & 174.79 & Germany \\
\hline Raiffeisen International & 111.86 & Austria \\
\hline
\end{tabular}

Source: www.eba.com and Annual Reports.

In detail, the sample consists of 36 banking groups belonging to different geographic areas (Table 1). The most represented areas, both for the number of banks and for assets administered, are Anglo-Saxon and German. In fact, there are six British banks, which in total run $23 \%$ of the total assets attributable to the whole sample of banks surveyed and 6 German banks. Following are France and Spain, represented by 5 and 4 banks respectively, Sweden with 4 banks, Belgium with 3 banks, Italy, Denmark and Austria with 2 banks, and finally Norway and the Netherlands with only 1 intermediary.

\subsection{The Elaboration of the "ESG-remuneration Performance Rating"}

In order to answer our research questions based on the analysis of the degree, the frequency, and above all the intersive use of non-financial metrics, in the context of banks equity incentives, a quantitative score (named "ESG-remuneration performance rating") was elaborated. Such a score aims at summarizing the performance of banks in this area by identifying the most virtuous behaviors. Preliminary, the analysis focused on the elaboration of a survey model consisting of 15 basic information (Table 2). Subsequently, by adopting the "content analysis approach" (Abbott and Monsen, 1979), all official documents on governance and remuneration policies were analyzed (Corporate Governance Report, Compensation/Remuneration Report, Annual Report, etc.), in order to valorize the elementary items and thus elaborate the final rating. As far as the model is concerned, it has been elaborated by reference to both operational practice and the approaches followed by banks (especially those of major size) and reference literature (Maas, 2016) and, finally, to some recent research reports that have developed this topic in depth (Vigeo, 2015). The joint analysis of these three sources has made it possible to become a model that, with regard to the prefix goals, is completely innovative. Most of the studies so far which have dealt with this subject (see paragraph 2) have only adopted a dichotomous system, assigning a value of 1 in the presence of use, by 
the banks, of non-financial metrics in the determination of equity incentives, and zero in the event of non-adoption (Russo and Harrison, 2005; Hong et al., 2015), without however discerning the methods of employment which of course could have been more or not in line with the regulatory requirements. The present work, however, attempted to overcome this simplistic approach with the aim of analyzing not only the degree of spread of such metrics in the banking sector but also the intensive use distinguishing between the most virtuous and the less compliant behavior.

As can be seen from Table 2, in more detail, the primary basic items of the model are to verify whether the bank uses non-financial metrics (item 1) and specifies typology and content (item 2). The choice to distinguish these two aspects depends on the behavior of some banks which, despite claiming to use such criteria, do not actually provide any additional information. Subsequently, the model investigates the number of non-financial performance criteria used (item 3), as well as their possible articulation and differentiation with each executive manager (item 4). Since the functions performed by each executive may differ, it would also be advisable for the quality performance indicators to be different in order to express, correctly, the actual contribution offered to the social value creation of the parent bank. The additional items concern the definition of the variable rate payout related to non-financial performance (item 5), the balance between financial criteria and non-financial criteria (item 7, distinguishing whether banks are limited to communicating that aspect or quantifying this ratio also in percentage terms), the weight of qualitative targets (compared to financial ones) in determining incentive wages (item 8) and, finally, the definition of quantitative targets for each non-financial criterion (item 6). With regard to this last aspect, the behavior of those banks is certainly more commendable than for a non-financial indicator, such as customer satisfaction, to set a quantitative target to be achieved. Only in this way, non-financial metrics take on a real impact, being subjected, just like financial ones, to a specific measurement process.

Lastly, the last items of the template focus on: a) using the bank score scorecard (item 9) in order to jointly reconcile the financial and non-financial criteria; b) the articulation/dissemination of such business and individual metrics (items 10 and 11), c) adoption of claw-back or malus clauses, or recovery of variable fees in the presence of non-ethical behavior by managers (item 12, serious violations of the Code of Conduct), d) including non-financial metrics also in the context of long term incentive plans (item 13), and (e) extending the use of the criteria not financially for senior management (not just board or executive managers, item 14) and, finally, f) the possible definition of a vesting period for non-financial metrics (item 15), ie a time span of waiting (At least 3-5 years) during which the basic conditions for the award of incentive pay must mature.

Attributes scores vary mostly between zero (non-respect of items or absence of related information) and 1 (bank compliance to basic information). Only for items 3 and 8 has been gradual valorization. Finally, the final rating is expressed in percentage terms and is given by the ratio between the value achieved by each bank relative to the maximum sum obtainable in the presence of an optimal valuation of all the items in the model.

Table 2. The model for the assignment of the "ESG-remuneration performance rating"

\begin{tabular}{|c|c|c|}
\hline N. & Items & Score \\
\hline 1 & Using non-financial performance criteria & 1 \\
\hline 2 & Disclosure of non-financial performance criteria & 1 \\
\hline 3 & Number of non-financial performance criteria used & $\begin{array}{c}\text { between } 0-3=1 \\
\text { between } 4-6=2 \\
\text { Over } 6=3\end{array}$ \\
\hline 4 & Differentiated qualitative targeting for each executive & 1 \\
\hline 5 & Definition of the $\%$ of variable remuneration as sociated with non-financial performance & 1 \\
\hline 6 & Definition of quantitative targets for each non-financial criterion & 1 \\
\hline 7 & Balancing non-financial criteria and financial criteria & $\begin{array}{c}\text { No quantification = } 1 \\
\text { With quantification }=2 \\
\text { between } 10-30 \%=1\end{array}$ \\
\hline 8 & Weight of qualitative targets & $\begin{array}{l}\text { between } 31-50 \%=2 \\
\text { Over } 51 \%=3\end{array}$ \\
\hline 9 & Using the balance scorecard & 1 \\
\hline 10 & Use non-financial criteria at individual and/orbusiness units & 1 \\
\hline 11 & Using non-financial criteria at enterprise level & 1 \\
\hline 12 & $\begin{array}{l}\text { Claw-back or malus clauses in the presence of non-ethical conduct by managers } \\
\text { (eg serious violations of code of conduct) }\end{array}$ & 1 \\
\hline 13 & Including non-financial metrics within LTIPs (Long Term Incentive Plan) & 1 \\
\hline 14 & Use non-financial criteria for senior management (not just board or executive managers) & 1 \\
\hline 15 & Vesting also for non-financial metrics & 1 \\
\hline
\end{tabular}

Source: our computation. 


\section{Results}

\subsection{The Degree and Intensive Use of Non-financial Performance Indicators: Analysis of the Survey Model}

The first output of the analysis relates to the values obtained from the individual items of the survey model (Table 3). The results seem encouraging, though not entirely satisfactory. In fact, it is possible to identify both some positive trends and also many gaps and practices which are still inadequate. The first positive aspect relates to the number of banks using non-financial criteria in the elaboration of their pay policies, which has clearly increased in the three-year survey (item 1). By the end of 2016, almost $90 \%$ of the investigated intermediaries were in line with this ethical behavior. On the contrary, a less positive aspect concerns the disclosure that banks publish on this criteria (item 2): in this case, the maximum percentage (reached in 2016) stops at $75 \%$. This discrepancy between the percentage of use of qualitative criteria and disclosure reveals that at present there are still some banks (increasing from 2014 to 2016) that merely affirm to use these metrics without, however, listing or indicating them in any way.

This is the case, for example, of Caixabank which only states that: "Both quantitative (financial) and qualitative (non-financial) criteria are taken into account when assessing performance and evaluating indi vidual results. In general, quantitative criteria are more frequently available at an institution-wide level, while qualitative factors are usually assessed at the individual level, where they are more relevant. These must be clearly specified and documented" (Caixabank, 2016: 6).

Continuing with the analysis, a further positive aspect relates to the number of non-financial performance criteria used by banks (item 3). Even then, the trend is positive: between 2014 and 2016, intermediaries broaden the range of non-financial measures, undoubtedly highlighting greater sensitivity to this problem. However, if one tries to check whether banks differentiate qualitative criteria in relationship to each single executive (item 4), then the data suddenly collapses, reaching at most $11.1 \%$ in 2016. This ethical behavior is only attributable to a few banks, including the British HSBC and Lloyds Banking, to which BNP Paribas and Credit Agricole were added in 2015-2016. The vast majority of the investigated intermediaries, therefore, choose to apply this criteria in a homogeneous and unambiguous manner without considering the specificity of the role and functions covered by each executive manager.

Further criticalities also emerge from the analysis of the subsequent items, a circumstance that denotes the presence of behavioral standards that are likely to have a large margin of improvement. Indeed, there are still a small number of banks that report the percentage of variable remuneration linked to non-financial criteria (approximately 35\% in 2016; item 5), those that define the quantitative targets associated with such metrics (between 15 and $20 \%$ in the three-year survey, item 6), as well as intermediaries extending the use of non-financial criteria to senior management (19.4\% in all survey years, item 14) or they define a vesting period, ie a waiting period during which conditions (temporal and non) must mature so that equity incentives can be attributed (only $11 \%$ at the end of 2016, item 15). However, greater compliance emerges with regard to the articulation in the use of non-financial criteria (items 9 and 10). In fact, most banks declare that they use such metrics at enterprise, business, and individual level, thus meeting a correct regulatory requirement.

Moreover, banks over and above the average (about $56 \%$ at the end of 2016) are using appropriate claw-back or malus arrangements of variable remuneration in the presence of non-ethical conduct by the manager (item 12), while there are fewer intermediaries adopting non-financial metrics for both bonuses and long-term incentives (around $42 \%$ and $44 \%$ in the three-year survey; item 13). Finally, with respect to the balance between financial and qualitative criteria, although most banks (55.6\% throughout the three-year period, item 7) are concerned with estimating and reporting this ratio, however the quantity of non-financial indicators is still somewhat reduced compared to economic ones (on average, the weighting of non-financial indicators is between $31 \%$ and $50 \%$ ), but also the use of the balance scorecard as a strategic tool to ensure the balance between the parameters of financial nature, including the Total Shareholder Return, TSR (Note 6) and non-financial factors is still confined to about one third (exactly $27.8 \%$ in 2016) of sample banks (item 9).

Overall, the analysis shows a high heterogeneity in the behavior of banks. Indeed, even in the presence of sufficiently detailed indications, information is often not detectable in homogeneous environments. In some cases, the list of non-financial performance appraisal metrics is placed in the section on the description of variable remuneration; in other cases, however, the bank provides information in the general description of remuneration policy. It is obvious, therefore, that some intermediaries pay more attention to the use of such indicators, while in other circumstances it seems that the information is only present to appear compliant with the regulations. In any case, the most important aspect is the almost generalized absence of a clear description not only of how these indicators are used but also of their respective measurement methods. As mentioned above, 
the use of quantitative targets associated with each non-financial criterion is confined to only $21 \%$ of banks (the highest value of 2016). In other words, there is no fundamental information to understand the actual use of non-financial measures, or the way in which they are measured. This aspect applies to all the parameters (see below): for example, how is compliance measure with the rules? Regarding customer satisfaction? Brand value or gender diversity? (Maybe through the number of women in board?). In fact, these are important questions whose presence raises little doubt as to the concrete application of the qualitative criteria and, therefore, their effectiveness not only in mitigating the weight of financial performance but above all in conditioning the effective delivery of incentive pay.

Table 3. The bank variables considered in the analysis

\begin{tabular}{|c|c|c|c|c|}
\hline N. & Items & 2014 & 2015 & 2016 \\
\hline 1 & Using non-financial performance criteria & $83.3 \%$ & $86.1 \%$ & $88.9 \%$ \\
\hline 2 & Disclosure of non-financial performance criteria & $72.2 \%$ & $72.2 \%$ & $75.0 \%$ \\
\hline \multirow[t]{4}{*}{3} & Number of non-financial performance criteria used & $69.4 \%$ & $69.4 \%$ & $72.2 \%$ \\
\hline & a) Between 0-3 & $36.1 \%$ & $27.8 \%$ & $30.6 \%$ \\
\hline & b) Between 4-6 & $22.2 \%$ & $25.0 \%$ & $22.2 \%$ \\
\hline & c) Over 6 & $11.1 \%$ & $16.7 \%$ & $19.4 \%$ \\
\hline 4 & Differentiated qualitative targeting for each executive & $8,3 \%$ & $8.3 \%$ & $11.1 \%$ \\
\hline 5 & $\begin{array}{l}\text { Definition of the } \% \text { of variable remuneration associated with } \\
\text { non-financial performance }\end{array}$ & $31.9 \%$ & $31.9 \%$ & $34.7 \%$ \\
\hline 6 & Definition of quantitative targets for each non-financial criterion & $15.3 \%$ & $18.1 \%$ & $20.8 \%$ \\
\hline \multirow[t]{3}{*}{7} & Balancing non-financial criteria and financial criteria & $55.6 \%$ & $55.6 \%$ & $55.6 \%$ \\
\hline & a) No quantification & $13.9 \%$ & $13.9 \%$ & $13.9 \%$ \\
\hline & b) With quantification & $41.7 \%$ & $41.7 \%$ & $41.7 \%$ \\
\hline \multirow[t]{4}{*}{8} & Weight of qualitative targets & $47.2 \%$ & $47.2 \%$ & $47.2 \%$ \\
\hline & a) Between 10-30\% & $13.9 \%$ & $13.9 \%$ & $13.9 \%$ \\
\hline & b) Between $31-50 \%$ & $25.0 \%$ & $19.4 \%$ & $16.7 \%$ \\
\hline & c) Over $51 \%$ & $8.3 \%$ & $13.9 \%$ & $16.7 \%$ \\
\hline 9 & Using the balance scorecard & $16.7 \%$ & $16.7 \%$ & $27.8 \%$ \\
\hline 10 & Use non-financial criteria at individual and / or business units & $50.0 \%$ & $55.6 \%$ & $61.1 \%$ \\
\hline 11 & Using non-financial criteria at enterprise level & $61.1 \%$ & $63.9 \%$ & $72.2 \%$ \\
\hline 12 & $\begin{array}{l}\text { Claw-back or malus clauses in the presence of non-ethical conduct } \\
\text { by managers (eg serious violations of code of conduct) }\end{array}$ & $55.6 \%$ & $55.6 \%$ & $55.6 \%$ \\
\hline 13 & $\begin{array}{l}\text { Including non-financial metrics within LTIPs (Long Term Incentive } \\
\text { Plan) }\end{array}$ & $41.7 \%$ & $44.4 \%$ & $44.4 \%$ \\
\hline 14 & $\begin{array}{l}\text { Use non-financial criteria for senior management (not just board or } \\
\text { executive managers) }\end{array}$ & $19.4 \%$ & $19.4 \%$ & $19.4 \%$ \\
\hline 15 & Vesting also for non-financial metrics & $8.3 \%$ & $11.1 \%$ & $11.1 \%$ \\
\hline
\end{tabular}

Source: our computation.

\subsection{The Behavior of European Banks: Evolution and Trend of Score at Individual and Geographical Level}

Continuing with the analysis, interesting considerations come from Figure 1, which shows, for each year of the survey, a ranking of intermediaries analyzed on the basis of their final rating (ESG-remuneration performance score). Even then, it is possible to observe the considerably higher position assumed by the English bank Lloyds Banking, the ninth among the European intermediaries analyzed for assets (less than one million euros, see Table 1), although in 2016 that bank shares first place with HSBC, another English bank. This fact highlights the absence of a significant relationship between compliance with the performance criteria regulations to be used in preparing pay rates and bank size.

Overall, comparing the three years, there is a clear prevalence among the first positions of banks of English nationality, as well as of the Belgian ING Groep bank, which is in fourth place in the three-year period considered. The position of the Dutch bank ABN Amro, of the German bank Deutsche Bank, of the French bank Credit Agricole and of Banco Santander appears satisfactory. As far as Italian banks are concerned, the position of Unicredit, which certainly holds the confrontation with the major international banking players, appears to be significant. Lastly, even in 2016 there are banks which, in the context of their corporate documents, do not report any information on non-financial performance indicators and are thus placed in the last positions in the ranking. 

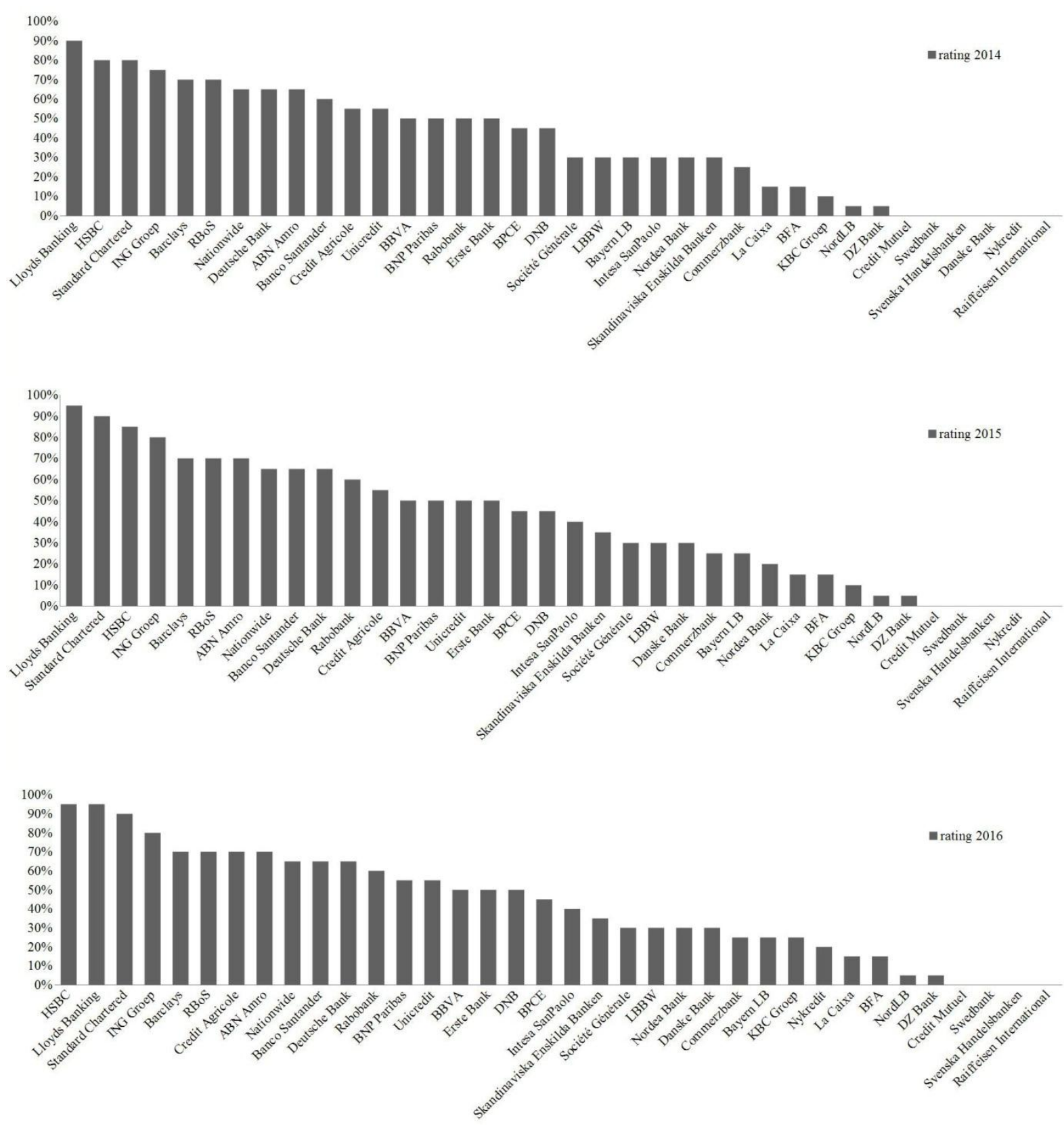

Figure 1. Rate of use of non-financial performance evaluation metrics: a ranking of European banks (years 2014-2016)

Subsequently, putting together the information obtained for each bank, the average final rating per country expressed in percentage terms was determined (Table 4). The growing trend in the score reflects gradual adjustments to new regulatory obligations as well as banks' awareness of the importance of using and disseminating information on non-financial performance indicators. Banks showing a higher level of score belong to those countries (England, The Netherlands, Belgium, Norway and Italy) where evidently the implementation of the new regulatory framework on managerial remuneration is at a more advanced stage. Moreover, the strengthening of the disclosure of managerial remuneration makes these countries particularly virtuous in terms of the modalities and tools adopted to reach a new regulatory vision for management compensation. 
Table 4. ESG-remuneration performance rating: descriptive variables and geographic trends (percentages values, years 2014-2016)

\begin{tabular}{|c|c|c|c|c|}
\hline Country & $2014(\%)$ & $2015(\%)$ & $2016(\%)$ & $\Delta$ 2014-2016 (\%) \\
\hline United Kingdom & 75.83 & 79.17 & 80.83 & +6.59 \\
\hline Netherlands & 65.00 & 70.00 & 70.00 & +7.69 \\
\hline Belgium & 45.00 & 50.00 & 55.00 & +22.22 \\
\hline Norway & 45.00 & 45.00 & 50.00 & +11.11 \\
\hline Italy & 42.50 & 45.00 & 47.50 & +11.76 \\
\hline France & 36.00 & 36.00 & 40.00 & +11.11 \\
\hline Spain & 35.00 & 36.25 & 36.25 & +3.57 \\
\hline Germany & 26.67 & 25.83 & 25.83 & -3.12 \\
\hline Denmark & 0.00 & 15.00 & 25.00 & +66.67 \\
\hline Austria & 25.00 & 25.00 & 25.00 & 0.00 \\
\hline Sweden & 15.00 & 13.75 & 16.25 & +8.33 \\
\hline Average & 38.19 & 40.14 & 42.50 & +11.27 \\
\hline Median & 37.50 & 42.50 & 42.50 & +13.33 \\
\hline Stand. Dev. & 27.68 & 28.57 & 28.37 & +2.52 \\
\hline Min. & 0.00 & 0.00 & 0.00 & 0.00 \\
\hline Max & 90.00 & 95.00 & 95.00 & 5.56 \\
\hline
\end{tabular}

Table 5. ESG-remuneration performance rating: variables and measurement score

\begin{tabular}{|c|c|c|c|c|}
\hline \multicolumn{5}{|c|}{ ESG-remuneration performance rating } \\
\hline Measurement & Variables & $2014(\%)$ & $2015(\%)$ & $2016(\%)$ \\
\hline Environmental $(E)$ & Environmental sustainability & 2.8 & 2.8 & 2.8 \\
\hline \multirow[t]{15}{*}{$\operatorname{Social}(S)$} & Customer satisfaction & 47.2 & 47.2 & 52.8 \\
\hline & Employment satisfaction & 19.4 & 33.3 & 36.1 \\
\hline & Reputation & 11.1 & 16.7 & 19.4 \\
\hline & Corporate Social Responsibility & 16.7 & 22.2 & 19.4 \\
\hline & Customers relationships & 11.1 & 16.7 & 16.7 \\
\hline & $\begin{array}{l}\text { Contribution to growth and } \\
\text { profitability }\end{array}$ & 8.3 & 11.1 & 16.7 \\
\hline & Net Promoter Score & 8.3 & 13.9 & 11.1 \\
\hline & Digital active customer growth & 2.8 & 5.6 & 8.3 \\
\hline & Leadership & 8.3 & 5.6 & 5.6 \\
\hline & Brand Value & 5.6 & 5.6 & 5.6 \\
\hline & Stakeholder engagement & 5.6 & 5.6 & 5.6 \\
\hline & Product innovation & 0.0 & 5.6 & 5.6 \\
\hline & Team work & 2.8 & 2.8 & 2.8 \\
\hline & Collaboration & 2.8 & 2.8 & 2.8 \\
\hline & Net Trust Score & 2.8 & 2.8 & 2.8 \\
\hline \multirow{11}{*}{$\begin{array}{l}\text { Corporate } \\
\text { Governance }(C G)\end{array}$} & Vision \&Strategy & 27.8 & 33.3 & 38.9 \\
\hline & Respect for risk management policy & 30.6 & 36.1 & 33.3 \\
\hline & Costs Efficiency & 13.9 & 16.7 & 25.0 \\
\hline & Quality of profits & 25.0 & 25.0 & 19.4 \\
\hline & Compliance & 5.6 & 13.9 & 13.9 \\
\hline & Culture & 5.6 & 11.1 & 11.1 \\
\hline & Efficiency of functions & 8.3 & 8.3 & 8.3 \\
\hline & $\begin{array}{l}\text { Individual/group performance and } \\
\text { divisional level }\end{array}$ & 5.6 & 5.6 & 5.6 \\
\hline & Board diversity & 2.8 & 5.6 & 5.6 \\
\hline & Financial Crime Risk Mitigation & 2.8 & 5.6 & 5.6 \\
\hline & Operational risk & 2.8 & 2.8 & 2.8 \\
\hline
\end{tabular}

\subsection{Non-financial Performance Metrics}

The final step in the analysis was to catalog all the non-financial performance criteria used by the banks, highlighting the respective degree of diffusion in the sample analyzed for the three-year survey. As Figure 2 shows, in total, the qualitative metrics used are 27, divided into three different universes (Table 5): Environmental (E), Social (S) and Corporate Governance (CG). An extensive approach has been used, by including all the qualitative indicators that banks claim to adopt, although in some cases (for example "Costs Efficiency", "Quality of profits" and "Contribution to growth and profitability") they are not closely related to the universe they are been included in. The first aspect that emerges concerns the high number of these criteria and their high diversification. The analysis, indeed, shows a strong heterogeneity in the way banks behave choosing to use different criteria and sometimes even difficult interpretation and identification. Among the most ambiguous criteria, can be included "Culture" and "Leadership" metrics because of the indeterminacy of the 
respective measurement methods on which, as discussed above, banks do not give any information.

Overall, the most widely used metric is customer satisfaction in its various aspects (customer satisfaction, customer retention and customer experience). Indeed, this goal is present in the majority of Remuneration reports: it represents the first value the banks follow in the articulation of their non-financial performance. Moreover, the centrality of the customer is highlighted by the use of two other indicators associated with it, referring to the Net Promoter Score (NPS), an alternative customer satisfaction management tool for assessing customer loyalty and the "Digital active customer growth", a direct criterion highlighting the growth trend in the use of virtual tools by bank customers.

Following, always in the prevailing position, the non-financial criteria for the implementation of the company strategy, as well as the satisfaction and retention of the employees. Even in that case, the spread appears to be adequate, albeit minor in relation to the importance attributed to customers. Moreover, there is also a strong orientation of the banking system to use the qualitative criterion of "Respect for risk management policy" and this is in tune with the "dogmas" of the new regulations which, on several occasions, reiterates the need that Remuneration practices are strongly linked to the bank's risk profile. Then, with more homogeneous diffusion rates, the "Costs efficiency", "Corporate Social Responsibility", "Quality of profits", "Reputation", "Compliance" criteria are followed. Also, some qualitative criteria that can be attributed to the corporate governance area ("Compliance/Board diversity") as well as those of an individual character ("Team work") are less frequent. Last but not least, the almost total lack of interest of banks towards environmental performance. In fact, only a very small percentage of intermediaries claim to link incentive wages to the results obtained in terms of environmental sustainability.

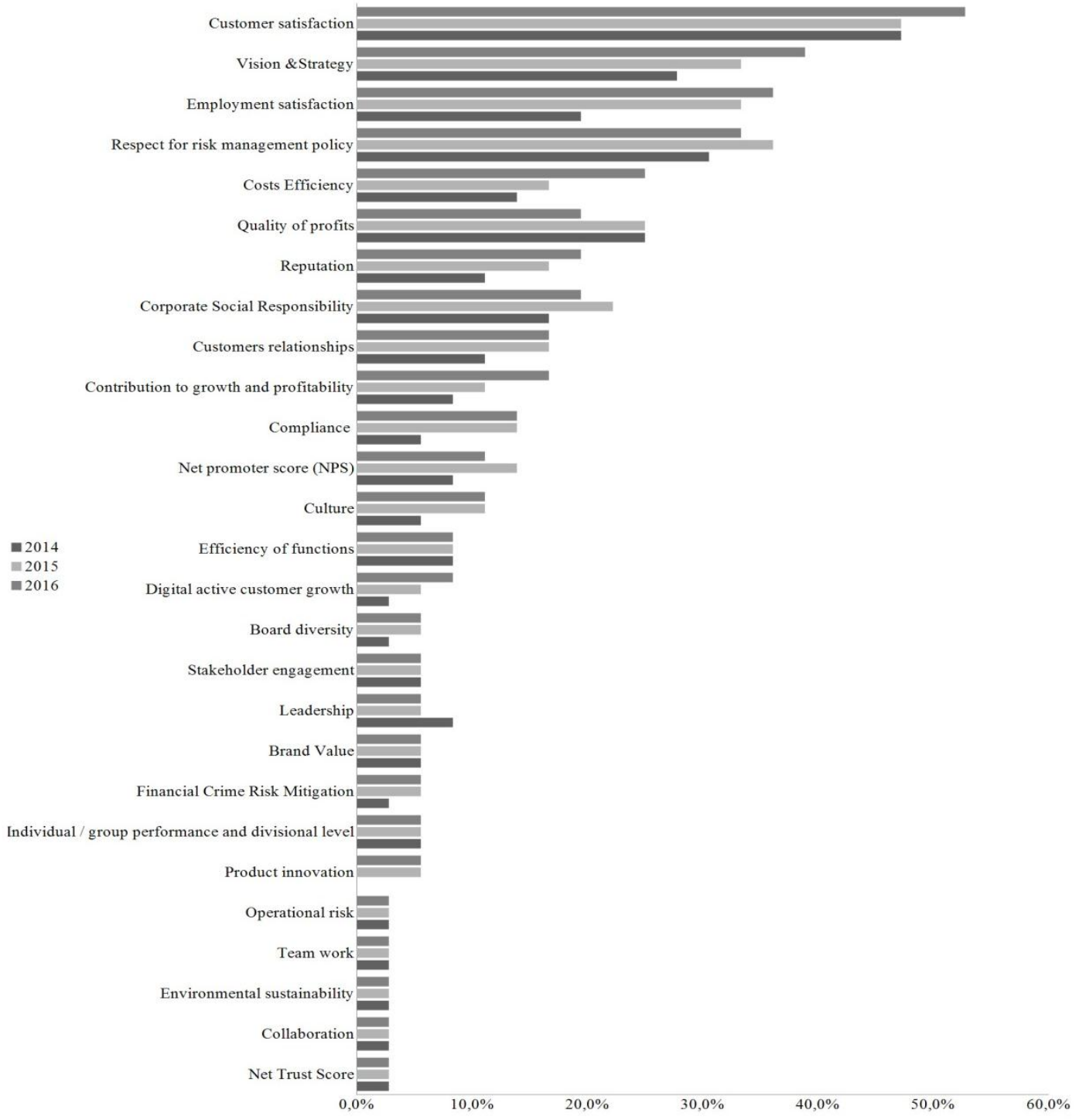

Figure 2. Non-financial performance evaluation metrics: degree of distribution at banks (years 2014-2016) 


\section{Discussion and Conclusions}

One of the most innovative aspects of the current banking regulation on executive compensation is certainly the inclusion of qualitative (or non-financial) metrics among the performance criteria to which incentive pay is attached. In other words, the regulator requires banks to link manage rial compensation not only to the economic value, but also to the social value, that is the added value realized for the benefit of all stakeholders. On the basis of these considerations, this paper aimed to answer the following research questions: a) verify the adoption of such qualitative metrics by banks compensation programs; b) analyze the modality and the intensity of use of such indicators by the financial sector in recent years (2014-2016). In order to reach these goals, a sample of 36 European banking groups belonging to different geographic areas was analized and for each financial firm a quantitative score (called ESG-remuneration performance rating) was elaborated.

Main results are incuraging, but they denote some negative aspects. Indeed although the response of the European banking system appears to be positive (almost all of the banks examined declare at the end of 2016 to use these metrics), the empirical analysis also highlighted some critical issues. While, on the one hand, the spread of such metrics is quite satisfactory, the intensive use, synthesized by the "ESG-remuneration performance score", is still inadequate. More in detail, despite some ethical behavior, mainly attributable to British banks (whose ratings are always more than 60\%), most of the other G-SIIs in Europe are characterized by more standardized and partly deficient approaches. This is evidenced by the average value of the "ESG-remuneration performance rating" that, for all three years of survey (2014-2016), never exceeds 50\%, although it shows a growth trend of around $11 \%$. To affect these values some banks do not seem to clearly follow this behavior pattern.

The first issue concerns the level of disclosure that often is inadequate. A significant percentage of banks, indeed, although declaring to use non-financial metrics, subsequently give no evidence by not even communicating the list of criteria chosen. A further gap involves the subdivision of non-financial metrics to each executive. In particular, most banks do not provide such articulation by implying that the same criteria and the same level apply for each manager. Moreover, is it still minority the percentuage of the banks that use the balance scorecard to achieve balance between financial targets and non-financial metrics. Finally, there is limited information on the methodologies for measuring non-financial metrics, a fact that negatively affects both the understanding of the link between pay and social value produced by the bank, and the ability of the managers to perceive a direct link between their behavior and the performance of the qualitative indicators. The aspect of measurability of qualitative performance is very important. Indeed, this question is undoubtedly the main juncture around which, in the coming years, both banks and Supervisory Authorities will have to concentrate so that the link between remuneration policies and non-financial performance can be real and not just formal.

Finally, it is appropriate to propose some policy guidelines. On the one hand, it would certainly be useful for banks to increase the number of non-financial criteria adopted (in their incentive remuneration), on the other hand, this expansion should not pose a risk of creating perverse incentives or additional modalities only to increase managerial compensation without promoting, at the same time, a holistic approach to sustainable performance. Moreover, as mentioned above, great attention has to be paid to the question of the measurability of such metrics, which must also be "materials", and to rely on important aspects for banking. Lastly, it is highly appropriate that qualitative measurements are always accompanied by an ex-ante indication of the objective parameters to be considered in the evaluation, the description of the expected performance and the specification by the manager responsible for the evaluation. Continuing, further reflections may also be made in relation to some components of the bank's governance system. Board and/or committees' charters should, indeed, include adequate forecasts for managers to be urged to use ESG metrics. The presence of well-defined roles and responsibilities on the use of these criteria is certainly an important sign for investors who will thus appreciate and include in their investment decisions that aspect. It is more accurately formalized the responsibility for the use of ESG metrics by the company, the greater the incentives for investors to invest in that enterprise (UN PRI, 2012). Lastly, it is evident that linking ESG criteria to remuneration packages is not an end in itself, but requires, on the contrary, a simultaneous change in organization, as well as the emergence of an ethic widely-oriented business culture (The European Parliament and the Council of the European Union 2014; Morgan Stanley, 2016).

\section{References}

Abbott, W. F., \& Monsen, R. J. (1979). On the Measurement of Corporate Social Responsibility: Self-Reported Disclosures as a Method of Measuring Corporate Social Involvement. The Academy of Management Journal, 22(3), 501-515. https://doi.org/10.2307/255740 
Abdelmotaal, H., \& Abdel-Kader M. (2016). The use of sustainability incentives in executive remuneration contracts: Firm characteristics and impact on the shareholders' returns. Journal of Applied Accounting Research, 17(3), 311-330. https://doi.org/10.1108/JAAR-12-2013-0123

Banker, R. D., Potter, G., \& Srinivasan, D. (2000). An empirical investigation of an incentive plan that includes nonfinancial performance measures. Accounting Review, 75(1), 65-92. https://doi.org/10.2308/accr.2000.75.1.65

BCBS - Basel Committee on Banking Supervision. (2010). Compensation Principles and Standards Assessment Methodology. January.

BCBS - Basel Committee on Banking Supervision. (2011). Range of Methodologies for Risk and Performance Alignment of Remuneration. May.

Belcredi, M., \& Ferrarini G. (2013). Boards and shareholders in European listed companies. Facts, context and post-crisis reforms. Cambridge University Press. https://doi.org/10.1017/CBO9781139629126

Berrone, P., \& Gomez-Mejia, L. R. (2009a). The pros and cons of rewarding social responsibility at the top. Human Resource Management, 48(6), 959-971. https://doi.org/10.1002/hrm.20324

Berrone, P., \& Gomez-Mejia, L. R. (2009b). Environmental performance and executive compensation: An integrated agency-institutional perspective. Academy of Management Journal, 52(1), 103-126. https://doi.org/10.5465/AMJ.2009.36461950

Caixabank. (2016). Annual Report on the remuneration of the members of the members of the Caixabank, S.A. board of directors.

Campbell, K., Johnston, D., Sefcik, S. E., \& Soderstrom, N. S. (2007). Executive compensation and non-financial risk: An empirical examination. Journal of Accounting and Public Policy, 26(4), 436-462. https://doi.org/10.1016/j.jaccpubpol.2007.05.001

CEBS - Committee of European Banking Supervisors. (2010). Guidelines on Remuneration Policies and Practices. December.

Cordeiro, J., \& Sarkis, J. (2008). Does explicit contracting effectively link CEO compensation to environmental performance? Business Strategy and the Environment, 17(5), 304-317. https://doi.org/10.1002/bse.621

De Vincentiis, P. (2014). Lo status di banca sistemica gioca un ruolo significativo? Una verifica empirica sui Cds delle maggiori banche europee. Bancaria, 12, 12-27.

EBA. (2015). Guidelines on sound remuneration policies under Articles 74(3) and 75(2) of Directive 2013/36/EU and disclosures under Article 450 of Regulation(EU) No 575/2013, 21 December.

Flammer, C., Hong, B., \& Minor, D. (2016). Corporate Governance and the Rise of Integrating Corporate Social Responsibility Criteria in Executive Compensation: Antecedents and Outcomes. https://doi.org/10.2139/ssrn.2831694

FSB - Financial Stability Board. (2009). Principles for Sound Compensation Practices, Implementation Standards. September.

FSB - Financial Stability Board. (2015). Implementing the FSB Principles for Sound Compensation Practices and their Implementation Standards. Fourth progress report. November.

Harvard Business Review (2015). Best Performing CEOs in the World" assessment.

Hong, B., Li, Z. F., \& Minor, D. B. (2015). Corporate Governance and Executive Compensation for Corporate Social Responsibility. Harvard Business School Working Paper 16-014, August. https://doi.org/10.2139/ssrn.2553963

Iannuzzi, A. P. (2013). Le politiche di remunerazione nelle banche tra regolamentazione e best practices. Edizioni Scientifiche Italiane, Napoli.

Ittner, C. D., Larcker, D. F., \& Rajan, M. V. (1997). The choice of performance measures in annual bonus contracts. Accounting Review, 72(2), 231-255.

KPMG (2015). Directors' Remuneration 2015. October.

Maas, K. (2016). Do Corporate Social Performance Targets in Executive Compensation Contribute to Corporate Social Performance? Journal of Business Ethics. https://doi.org/10.1007/s10551-015-2975-8

Miles, P. C., \& Miles, G. (2011). Corporate social responsibility and executive compensation: exploring the link. 


\section{Social Responsibility Journal, 9(1), 76-90. https://doi.org/10.1108/17471111311307822}

Morgan Stanley. (2016). S+R Soundbite: How can ESG be embedded into Executive Compensation? May.

New Bridge Street. (2012). Report on FTSE 250 Director's Remuneration 2012/2013. London.

Russo, M., \& Harrison, N. (2005). Organizational design and environmental performance: Clues from the electronics industry. Academy of Management Journal, 48(4), 582-593. https://doi.org/10.5465/AMJ.2005.17843939

The European Parliament and the Council of the Europena Union. (2014). Directive 2014/95/EU amending Directive 2013/34/EU as regards disclosure of non-financial and diversity information by certain large undertakings and groups, 22 October.

UN PRI. (2012). Integrating ESG issues into executive pay.

Vigeo. (2012). ESG Incentives for Executives: current trends and best practices. Results of review conducted as a response to the PRI Secretariat call for research in February 2012.

Vigeo. (2015). Executive remuneration: Does social responsibility really matter? December.

\section{Notes}

Note 1. Although the work is the result of collaboration of two authors, sections 3.1, 3.2, 4.2 e 4.3 are attribute to Elisabetta D'Apolito while sections 1,2, 4.1 and 5 are attributed to Antonia Patrizia Iannuzzi.

Note 2. The ESG acronym consists of three words that, in turn, comprises three different universes. The first uni verse (Environmental) regards the environmental sustainability; the second (Social) refers to gender practices and stakeholders relationships; finally, the third universe (Governance) involves the management and control system of a company. For more detail, see Vigeo (2012).

Note 3. It is highlighted how such metrics are identified by the literature using non-converging expressions. The most frequent ones are: "non financial measures" (Banker et al., 2000); "CSR targets" (Maas, 2016), "ESG metrics/indicators" (Vigeo, 2015), "CSR contracting” (Flammer et al., 2016).

Note 4. This author defines non-financial metrics "CSR targets" and distinguishes them in two categories: a) soft (or qualitative) CSR targets and b) hard (or quantitative) CSR targets. The difference between the two types of metrics lies in the definition or not of a quantitative objective to be achieved. Indeed, the company could only specify whether it intends to reduce Co2 emissions or that it is committed to increasing the number of women in the board (soft CSR targets. On the contrary, the company could communicate the same intentions by establishing, for example, that $\mathrm{Co} 2$ reductions should be at least $20 \%$ or that the increase in women at the corporate governance should be at least $10 \%$.

Note 5. This refers, for example, to a "CSR sustainability committee", to using a "CSR sustainability index", or to adopting a "sustainability resource efficiency policy" (Abdelmotaal and Abdel-Kader, 2016).

Note 6. Total Shareholder Return is the most comprehensive measure of the value created by an enterprise for its shareholders. It is calculated using the following formula: (Final price of the share - Initial share price + Dividends paid in the period) / Initial price of the share. In summary, the calculation of this indicator shows the annual rate of return for an investor who has acquired a stock on X date and sold it on Y; Such calculation shall take into account all paid dividends reinvested in the security at the date of the coupon's breakdown.

\section{Copyrights}

Copyright for this article is retained by the author(s), with first publication rights granted to the journal.

This is an open-access article distributed under the terms and conditions of the Creative Commons Attribution license (http://creativecommons.org/licenses/by/4.0/). 